medRxiv preprint doi: https://doi.org/10.1101/2021.04.28.21256261; this version posted May 2, 2021. The copyright holder for this preprint (which was not certified by peer review) is the author/funder, who has granted medRxiv a license to display the preprint in perpetuity.

It is made available under a CC-BY-NC-ND 4.0 International license .

\title{
Aspirin and NSAID use and the risk of COVID-19
}

David A. Drew ${ }^{1,2 *}$, Chuan-Guo Guo ${ }^{1,2,3 *}$, Karla A. Lee ${ }^{4 *}$, Long H. Nguyen ${ }^{1,2,5}$, Amit D. Joshi ${ }^{1,2}$, Chun-Han Lo $^{1,2,6}$, Wenjie Ma ${ }^{1,2}$, Raaj S. Mehta ${ }^{1,2}$, Sohee Kwon ${ }^{1,2}$, Christina M. Astley ${ }^{7,8}$, Mingyang Song ${ }^{6,9}$, Richard Davies $^{10}$, Joan Capdevila ${ }^{10}$, Mary Ni Lochlainn ${ }^{4}$, Carole H. Sudre ${ }^{11}$, Mark S. Graham ${ }^{11}$, Thomas Varsavsky ${ }^{11}$, Maria F. Gomez ${ }^{12}$, Beatrice Kennedy ${ }^{13}$, Hugo Fitipaldi ${ }^{12}$, Jonathan Wolf ${ }^{10}$, Tim D. Spector ${ }^{4}$, Sebastien Ourselin $^{11}$, Claire J. Steves ${ }^{4}$, Andrew T. Chan ${ }^{1,2,8,14,15 \dagger}$

\section{Affiliations:}

${ }^{1}$ Clinical and Translational Epidemiology Unit, Massachusetts General Hospital and Harvard Medical School, Boston, MA, U.S.A.

${ }^{2}$ Division of Gastroenterology, Massachusetts General Hospital and Harvard Medical School, Boston, MA, U.S.A.

${ }^{3}$ Department of Medicine, Li Ka Shing Faculty of Medicine, University of Hong Kong, Hong Kong, China ${ }^{4}$ Department of Twin Research and Genetic Epidemiology, King's College London, London, U.K.

${ }^{5}$ Department of Biostatistics, Harvard T.H. Chan School of Public Health, Boston, MA, U.S.A.

${ }^{6}$ Department of Epidemiology, Harvard T.H. Chan School of Public Health, Boston, MA, U.S.A.

${ }^{7}$ Division of Endocrinology and Computational Epidemiology Lab, Boston Children's Hospital and Harvard Medical School, Boston, MA, U.S.A.

${ }^{8}$ Broad Institute of MIT and Harvard, Cambridge, MA, U.S.A.

${ }^{9}$ Department of Nutrition, Harvard T.H. Chan School of Public Health, Boston, MA, U.S.A.

${ }^{10}$ Zoe Global Ltd., London, U.K.

${ }^{11}$ School of Biomedical Engineering \& Imaging Sciences, King's College London, London, U.K.

${ }^{12}$ Department of Clinical Sciences, Lund University Diabetes Centre, Lund University, Malmö, Sweden

${ }^{13}$ Department of Medical Sciences, Molecular Epidemiology and Science for Life Laboratory, Uppsala University, Uppsala, Sweden.

${ }^{14}$ Department of Immunology and Infectious Disease, Harvard T.H. Chan School of Public Health, Boston, MA, U.S.A.

${ }^{15}$ Massachusetts Consortium on Pathogen Readiness

*Contributed equally to this work

$†$ To whom correspondence should be addressed: Andrew T. Chan, MD, MPH, Clinical \& Translational Epidemiology Unit, Massachusetts General Hospital, 100 Cambridge St. Boston, MA, 02114. achan@mgh.harvard.edu

One Sentence Summary: NSAID use is not associated with COVID-19 risk. 
medRxiv preprint doi: https://doi.org/10.1101/2021.04.28.21256261; this version posted May 2, 2021. The copyright holder for this preprint (which was not certified by peer review) is the author/funder, who has granted medRxiv a license to display the preprint in perpetuity.

It is made available under a CC-BY-NC-ND 4.0 International license .

Abstract: Early reports raised concern that use of non-steroidal anti-inflammatory drugs (NSAIDs) may increase risk of severe acute respiratory syndrome coronavirus 2 (SARS-CoV-2) disease (COVID-19). Users of the COVID Symptom Study smartphone application reported use of aspirin and other NSAIDs between March 24 and May 8, 2020. Users were queried daily about symptoms, COVID-19 testing, and healthcare seeking behavior. Cox proportional hazards regression was used to determine the risk of COVID-19 among according to aspirin or non-aspirin NSAID users. Among 2,736,091 individuals in the U.S., U.K., and Sweden, we documented 8,966 incident reports of a positive COVID-19 test over 60,817,043 person-days of follow-up. Compared to non-users and after stratifying by age, sex, country, day of study entry, and race/ethnicity, nonaspirin NSAID use was associated with a modest risk for testing COVID-19 positive (HR 1.23 [1.09, 1.32]), but no significant association was observed among aspirin users (HR 1.13 [0.92, 1.38]). After adjustment for lifestyle factors, comorbidities and baseline symptoms, any NSAID use was not associated with risk (HR 1.02 $[0.94,1.10])$. Results were similar for those seeking healthcare for COVID-19 and were not substantially different according to lifestyle and sociodemographic factors or after accounting for propensity to receive testing. Our results do not support an association of NSAID use, including aspirin, with COVID-19 infection. Previous reports of a potential association may be due to higher rates of comorbidities or use of NSAIDs to treat symptoms associated with COVID-19. 
medRxiv preprint doi: https://doi.org/10.1101/2021.04.28.21256261; this version posted May 2, 2021. The copyright holder for this preprint (which was not certified by peer review) is the author/funder, who has granted medRxiv a license to display the preprint in perpetuity.

It is made available under a CC-BY-NC-ND 4.0 International license .

\section{Introduction}

As the severe acute respiratory syndrome coronavirus 2 (SARS-CoV-2) disease (COVID-19) swept the globe, anecdotal reports of a potential exacerbating effect of non-steroidal anti-inflammatory drugs (NSAIDs), including ibuprofen and aspirin, on COVID-19 emerged, leading to some warnings against the use of NSAIDs(1-4). Concern was raised that ibuprofen, in particular, may increase angiotensin-converting enzyme 2 (ACE2) receptor expression(5), which may facilitate viral entry into host cells(6-9).

The association of medications with disease risk is often confounded by the indication for use or other comorbidities. For example, recent studies have shown that angiotensin converting enzyme inhibitors (ACEis), which were also hypothesized to predispose to risk of severe COVID-19 due to upregulation of the ACE2 pathway, have shown no increase in risk after accounting for hypertension or other cardiovascular risk factors(10-13) Similarly, NSAIDs are often taken by older adults for comorbid conditions that, in turn, are associated with COVID-19. In particular, aspirin is used in the primary and secondary prevention of cardiovascular disease and cancer.(14) NSAIDs are also often used to treat symptoms associated with COVID19, including fever, myalgias, and sore throat. Thus, we prospectively surveyed individuals in the United States, United Kingdom, and Sweden using the COVID Symptom Study app about use of NSAIDs, risk factors for COVID-19, and disease symptoms to investigate if these agents were associated with incident COVID-19 outcomes.

\section{Results}

Association of use of any NSAID and COVID-19

Since March 26, we enrolled 2,736,091 study participants in the COVID Symptom Study and documented 8,966 reports of a positive COVID-19 test over 60,817,043 person-days of follow-up across the three countries. The baseline characteristics of the study cohort appear as Table 1. Regular NSAID users were older, were more likely to be obese $(\mathrm{BMI} \geq 30)$ and have comorbidities including diabetes, heart, kidney, lung diseases, or cancer and report taking other medications. Compared to non-users, we observed a modest association for any NSAID users with COVID-19 (stratified hazard ratio $[\mathrm{HR}]=1.22 ; 95 \%$ confidence interval $[\mathrm{CI}]: 1.13,1.32$ ) when 
medRxiv preprint doi: https://doi.org/10.1101/2021.04.28.21256261; this version posted May 2, 2021. The copyright holder for this preprint (which was not certified by peer review) is the author/funder, who has granted medRxiv a license to display the preprint in perpetuity. It is made available under a CC-BY-NC-ND 4.0 International license.

stratifying for age, sex, race/ethnicity, date of study entry, and country (Table 2a). After additional

multivariable adjustment for non-NSAID medication use and comorbidities, including diabetes, kidney, heart, and lung disease and cancer, as well as risk factors for SARS CoV-2 exposure (community or occupational contact), the comorbidity-adjusted hazard ratio was attenuated to 1.15 (95\% CI: 1.06, 1.24). After further adjustment for symptoms reported at baseline, the comorbidity and symptom-adjusted HR was further attenuated to 1.02 (95\% CI: $0.94,1.10)$.

\section{Association of any NSAID use with treatment seeking}

Because early reports suggested that NSAID use may be associated with more severe cases of COVID-19, we next investigated whether there was an association between NSAID use and COVID-19 cases seeking treatment in a hospital or clinic. Stratified models demonstrated an increased risk of seeking treatment for COVID-19 $(\mathrm{HR}=1.77 ; 95 \% \mathrm{CI} 1.52,2.06)$ that was attenuated after adjusting for comorbidities and symptoms which may have led using NSAIDs at baseline (comorbidity and symptom-adjusted HR=1.13;0.96, 1.32). Among the full cohort, we also observed no clear associations of any NSAID use with risk of COVID-19 compared to no NSAID use according to subgroups of demographic, lifestyle, and comorbidity factors (Figure 1) after accounting for multiple testing.

Association with COVID-19 risk according to aspirin or non-aspirin NSAID use

Within the sub-cohort of individuals who were asked separately about aspirin and other NSAID use

(Supplemental Table 1, Materials and Methods), we also found that non-aspirin NSAID use was not associated with COVID-19 after adjustment for comorbidities, risk factors and COVID-19 symptoms at baseline which may confound use of other NSAIDs (Table 2b). Compared with non-users of any aspirin or NSAIDs, aspirin use was not significantly associated with risk of testing positive for COVID-19 in any models (comorbidity and symptom-adjusted $\mathrm{HR}=1.03 ; 95 \% \mathrm{CI}: 0.83,1.28$ ). Further, it appeared any potential association between NSAIDs and seeking treatment for COVID-19 was restricted to non-aspirin NSAID users 
medRxiv preprint doi: https://doi.org/10.1101/2021.04.28.21256261; this version posted May 2, 2021. The copyright holder for this preprint (which was not certified by peer review) is the author/funder, who has granted medRxiv a license to display the preprint in perpetuity.

It is made available under a CC-BY-NC-ND 4.0 International license .

with no apparent association among aspirin users. Moreover, no significant association was observed after adjusting for comorbidities and symptoms.

Overall, users of other NSAIDs reported a greater prevalence of symptoms associated with COVID-19, including those that may prompt individuals to use non-aspirin NSAIDs. The most frequently observed symptoms across the cohort were fatigue, headache, shortness of breath, and cough; however, headache, myalgias (pain), and fever appeared enriched among NSAID users, especially non-aspirin NSAID users (Supplemental Table 2). Individuals using aspirin reported fewer symptoms overall (17.3\% reporting at least one symptom) compared to both non-users (22\%) and those reporting use of other NSAIDs (34.2\%)

(Supplemental Table 2). We considered the possibility that NSAID use for treatment of symptoms and aspirin use for chronic disease prevention among those with underlying health conditions could be associated with a greater likelihood of receiving and reporting testing, potentially inducing a selection bias. However, a multivariable-adjusted IPW Cox proportional hazards model weighted by predictors of testing demonstrated no further effect on the fully adjusted association of NSAIDs with COVID-19 incidence (IPW-adjusted HR = 1.02; 95\%CI: $0.93,1.12$ ). Further, we restricted the analysis to only those receiving testing and found no association for any NSAIDs with risk of COVID-19 in any model (comorbidity and symptom-adjusted HR=0.93; 95\% CI: $0.86,1.01)$ Taken together, these additional analyses confirm that NSAID use does not appear to increase the risk of testing positive for COVID-19.

\section{Discussion}

In this prospective analysis of more than 2.7 million users of a real-time symptom tracker smartphone app, NSAID use, including use of aspirin, was not associated with a higher risk of testing positive for COVID-19. Any initial association with NSAID use is attenuated after adjustment for important confounders such as lifestyle, demographic, and comorbidity factors. There was also no observed risk of seeking or receiving treatment for COVID-19 and this association was not impacted by the propensity to receive testing compared to individuals reporting no NSAID use. 
medRxiv preprint doi: https://doi.org/10.1101/2021.04.28.21256261; this version posted May 2, 2021. The copyright holder for this preprint (which was not certified by peer review) is the author/funder, who has granted medRxiv a license to display the preprint in perpetuity. It is made available under a CC-BY-NC-ND 4.0 International license.

These analyses indicate that initial anecdotal reports of a potentially harmful association of NSAID use with COVID-19 incidence due to hypothesized upregulation of ACE2 receptor expression were likely related to confounding. Predictors of COVID-19 severity (i.e. heart disease) and symptoms related to acute illness are both indications for which aspirin or non-aspirin NSAID use, respectively, may be recommended, which may have contributed to a positive association. Our results after adjusting for comorbidities and symptoms demonstrate that any putative risk of COVID-19 associated with reported NSAID use is likely due, in part, to these factors driving use of aspirin or NSAIDs. Baseline use of NSAIDs was nominally associated with COVID-19 risk and was non-significant among those cases tested or seeking treatment. This may suggest that individuals feeling unwell with COVID-19 symptoms (e.g. fatigue, aches/pains, fever or chills) may be more likely to use NSAIDs, particularly non-aspirin NSAIDS, for symptom management prior to seeking testing or treatment. As outlined by the FDA's guidance(3), labels on over-the-counter NSAIDs warn that "the pharmacological activity of NSAIDs in reducing inflammation, and possibly fever, may diminish the utility of diagnostic signs in detecting infections." Thus, individuals using NSAIDs for early symptoms may have been more likely to present to hospitals and clinics later in the disease course leading to anecdotal reports of higher disease severity associated with NSAID use. Indeed, we observed that reported symptom burden was higher among non-aspirin NSAID users. However, we found no increased risk of testing positive for COVID-19 when we weighted risk estimates for the propensity to receive a test or restricted our analyses to models to those who received testing. Furthermore, there was no association of aspirin, an agent which is not generally used for management of symptoms, and risk of testing positive.

These findings have important implications for aspirin use during the pandemic. Aspirin, unlike other NSAIDs (e.g. ibuprofen, naproxen), is more likely to be used chronically for its established anti-platelet effects via inhibition of prostaglandin synthase 1 (PTGS1 or cyclooxygenase $[\mathrm{COX}-1])(15,16)$ and recommended use in primary or secondary prevention of cardiovascular/thrombotic events and colorectal cancer(17). Moreover, the population most likely to use aspirin are those with comorbidities such as cardiovascular disease or diabetes, 
medRxiv preprint doi: https://doi.org/10.1101/2021.04.28.21256261; this version posted May 2, 2021. The copyright holder for this preprint

which have been associated with more severe COVID-19 outcomes.(6-8) Our data reassures patients and providers that decision-making regarding aspirin use need not incorporate concerns related to risk for COVID19 infection. Moreover, given emerging indications that venous thromboembolism is a prevalent complication in COVID-19(18) and suggestions that early anticoagulant intervention may improve prognosis(19), unnecessary cessation of maintenance aspirin could be particularly harmful for patients due to the potential for rebound hypercoagulability. Further studies are needed to examine a potential role for aspirin in the prevention of such complications with severe COVID-19 as well as if outcomes among those with established infection differ according to NSAID use, independent of comorbidities.

Our study has many strengths, including prospective collection of key relevant lifestyle and demographic factors, comorbidities, and symptom data among a large study population with sufficient longitudinal follow-up for clinical trajectories and COVID-19 infections during a critical phase of the pandemic. However, there are several limitations to our study. The nature of data collection relies on self-report and community testing practices. While we have accounted for multiple potential sources of potential confounding, there may be residual bias according to unmeasured confounders (e.g. access to healthcare, health-conscious behavior), as well as measurement bias (e.g. recall-bias for self-reports, NSAID use in response to COVID-19 infection), or selection bias (e.g. differential app participation or testing by NSAID use). To address these concerns, we adjusted for comorbidities for which aspirin use is an indication (e.g. heart disease) or baseline symptoms likely to prompt NSAID use (e.g. fever or headache). We also conducted sensitivity analyses in which we adjusted for the propensity to receive testing using IPW and restricted to those that received testing. Last, our approach through voluntary reporting is unlikely to be able to capture the effects of NSAIDs in relation to the most severe COVID-19 symptoms and complications.

In conclusion, we find no evidence to support an increased risk for COVID-19 in those that regularly use aspirin or non-aspirin NSAIDs. These findings may offer reassurance to patients and providers regarding the safety of 
medRxiv preprint doi: https://doi.org/10.1101/2021.04.28.21256261; this version posted May 2, 2021. The copyright holder for this preprint (which was not certified by peer review) is the author/funder, who has granted medRxiv a license to display the preprint in perpetuity.

It is made available under a CC-BY-NC-ND 4.0 International license .

continuing use of aspirin for prevention of cardiovascular disease or cancer and the use of NSAIDs for treatment of chronic pain or other inflammatory conditions during the COVID-19 pandemic.

\section{Materials and Methods}

\section{The COVID Symptom Study smartphone application}

The COVID Symptom Study smartphone application (“app”) is a freely available program developed by Zoe Global Ltd. with scientific input from researchers and clinicians at Massachusetts General Hospital and King's College London that offers participants the ability to report a range of baseline demographic information and comorbidities upon first use, as previously described.(20) Participants are encouraged to use the app daily, even when asymptomatic, to allow for the longitudinal, prospective collection of concomitant symptoms, COVID-19 testing results, treatment and outcomes. The app was launched in the UK (March 24, 2020), U.S. (March 29, 2020) and Sweden (April 29, 2020). The analyses were performed on data provided by all participants enrolled in the study through May 8th, 2020. Participants were recruited from the general public through media, social media, and traditional study recruitment outreach. Participants provided informed consent to the use of app data for research purposes and agreed to privacy policies and terms of use. This research study was approved by the Partners Human Research Committee (IRB 2020P000909), King's College London Ethics Committee (REMAS ID 18210, Review Reference LRS-19/20-18210), and the central ethics committee in Sweden (DNR 202001803).

Assessment of NSAID use, risk factors, symptoms, testing, and treatment.

On initiation of the study on March 24, 2020, participants were asked to provide demographic factors and answered separate questions about possible risk factors for COVID-19, including comorbidities and medication use, including NSAIDs, at baseline. Starting on March $30^{\text {th }}$ (coinciding with launch of the app in the U.S.) we 
medRxiv preprint doi: https://doi.org/10.1101/2021.04.28.21256261; this version posted May 2, 2021. The copyright holder for this preprint (which was not certified by peer review) is the author/funder, who has granted medRxiv a license to display the preprint in perpetuity.

It is made available under a CC-BY-NC-ND 4.0 International license.

began asking new users separate questions to distinguish regular aspirin use from other non-aspirin NSAIDS.

After enrollment, participants are prompted daily to report if they felt physically normal, and if not, their symptoms, including those possibly related to COVID-19 (i.e. presence of fever, persistent cough, fatigue, loss of smell/taste, and diarrhea, among others), as well as health care seeking behavior (i.e. whether they had been to the hospital and/or sought and received clinical treatment, including supplemental oxygen, invasive ventilation, intravenous fluids, or inhalers). Participants were also asked if they had been tested for COVID-19 (yes/no), and if yes, the results (none, negative, waiting for results, or positive).

\section{Statistical analysis}

For the main analysis, we included all individuals except those that had reported a positive COVID-19 test within 24 hours of enrolling in the study. We employed Cox proportional hazards regression to examine the association between regular use of any NSAID and risk of a positive COVID-19 test. The initial models (referred to as "multivariable stratified") were stratified by age, sex, date, country, and race/ethnicity. Subsequent models (referred to as "comorbidity-adjusted") additionally adjusted for covariates that were selected a priori based on putative risk factors and included self-reported height and weight calculated body mass index $(<18.5,18.5-24.9,25-29.9$, and $\geq 30 \mathrm{~kg} / \mathrm{m} 2)$, history of diabetes, heart disease, lung disease, kidney disease, current smoking status (each yes/no), limited mobility (homebound or walks with assistance of a cane or walker). Missing categorical data were included as a missing indicator. Because NSAID use, particularly non-aspirin NSAID use at baseline, may be confounded by COVID symptoms (i.e. fever, headache, aches/pain) that lead to their use, we additionally adjusted analyses for any baseline symptoms that were reported (referred to as "symptom adjusted"). To understand the differences associated with regular aspirin use versus NSAID use, we also limited the analysis to the sub-cohort that was asked separately about these beginning on March 30 . In sensitivity analyses, we limited the analysis to individuals who received testing. Using inverse probability weighting (IPW) for receiving a test based on age, country of residence, contact with individuals with suspected 
medRxiv preprint doi: https://doi.org/10.1101/2021.04.28.21256261; this version posted May 2, 2021. The copyright holder for this preprint (which was not certified by peer review) is the author/funder, who has granted medRxiv a license to display the preprint in perpetuity.

It is made available under a CC-BY-NC-ND 4.0 International license .

or documented COVID-19, being a healthcare worker, and reporting symptoms at baseline, we also conducted an IPW-adjusted Cox model to account for the propensity to receive a test.(21) In a secondary analysis, we examined the association of NSAIDs with COVID-19 requiring hospitalization or treatment as a proxy for disease severity. In addition, we stratified models according to comorbidities, lifestyle and sociodemographic factors to assess whether differences for the association between NSAIDs and COVID-19 or an interaction between factors and NSAIDs through inclusion of a multiplicative interaction term in the model was present among subgroups of the study population. Two-sided $p$-values $<0.05$ were considered statistically significant for the primary and secondary analyses. Interaction tests in stratified analyses were considered significant at $\mathrm{p}<0.005$ using Bonferroni multiple hypothesis adjustment $(\alpha=0.05 / 10$ stratification factors $=0.005)$. All analyses were performed using R 3.6.1 (Vienna, Austria).

\section{Supplementary Materials}

Table S1. Baseline characteristics according to use of aspirin, non-aspirin NSAIDs, or Both (Cohort restricted to $3 / 30$ baseline)

Table S2. Aspirin and non-aspirin NSAIDs and symptom occurrence

\section{References and Notes:}

1. G. A. FitzGerald, Misguided drug advice for COVID-19. Science 367, 1434 (2020).

2. U. National Health Service. (NHS UK, nhs.uk, 2020).

3. USFDA. (2020), vol. 2020.

4. G. Kolata, in The New York Times. (nytimes.com, nytimes.com, 2020), vol. 2020.

5. L. Fang, G. Karakiulakis, M. Roth, Are patients with hypertension and diabetes mellitus at increased risk for COVID-19 infection? Lancet Respir Med 8, e21 (2020).

6. W. J. Guan et al., Clinical Characteristics of Coronavirus Disease 2019 in China. N Engl J Med 382, 1708-1720 (2020). 
medRxiv preprint doi: https://doi.org/10.1101/2021.04.28.21256261; this version posted May 2, 2021. The copyright holder for this preprint (which was not certified by peer review) is the author/funder, who has granted medRxiv a license to display the preprint in perpetuity. It is made available under a CC-BY-NC-ND 4.0 International license .

7. J. J. Zhang et al., Clinical characteristics of 140 patients infected with SARS-CoV-2 in Wuhan, China. Allergy, (2020).

8. X. Yang et al., Clinical course and outcomes of critically ill patients with SARS-CoV-2 pneumonia in Wuhan, China: a single-centered, retrospective, observational study. Lancet Respir Med 8, 475-481 (2020).

9. N. Chen et al., Epidemiological and clinical characteristics of 99 cases of 2019 novel coronavirus pneumonia in Wuhan, China: a descriptive study. Lancet 395, 507-513 (2020).

10. G. Mancia, F. Rea, M. Ludergnani, G. Apolone, G. Corrao, Renin-Angiotensin-Aldosterone System Blockers and the Risk of Covid-19. N Engl J Med, (2020).

11. H. R. Reynolds et al., Renin-Angiotensin-Aldosterone System Inhibitors and Risk of Covid-19. N Engl J Med, (2020).

12. X. W. Xu et al., Clinical findings in a group of patients infected with the 2019 novel coronavirus (SARS-Cov-2) outside of Wuhan, China: retrospective case series. BMJ 368, m606 (2020).

13. C. Wu et al., Risk Factors Associated With Acute Respiratory Distress Syndrome and Death in Patients With Coronavirus Disease 2019 Pneumonia in Wuhan, China. JAMA Intern Med, (2020).

14. D. A. Drew, Y. Cao, A. T. Chan, Aspirin and colorectal cancer: the promise of precision chemoprevention. Nat Rev Cancer 16, 173-186 (2016).

15. C. D. Funk, Prostaglandins and leukotrienes: advances in eicosanoid biology. Science 294, 1871-1875 (2001).

16. M. J. Thun, E. J. Jacobs, C. Patrono, The role of aspirin in cancer prevention. Nature Reviews Clinical Oncology 9, 259-267 (2012).

17. K. Bibbins-Domingo, U. S. P. S. T. Force, Aspirin Use for the Primary Prevention of Cardiovascular Disease and Colorectal Cancer: U.S. Preventive Services Task Force Recommendation Statement. Ann Intern Med 164, 836-845 (2016). 
medRxiv preprint doi: https://doi.org/10.1101/2021.04.28.21256261; this version posted May 2, 2021. The copyright holder for this preprint (which was not certified by peer review) is the author/funder, who has granted medRxiv a license to display the preprint in perpetuity. It is made available under a CC-BY-NC-ND 4.0 International license.

18. J. Nahum et al., Venous Thrombosis Among Critically Ill Patients With Coronavirus Disease 2019 (COVID-19). JAMA Netw Open 3, e2010478 (2020).

19. P. Horby et al., Effect of Dexamethasone in Hospitalized Patients with COVID-19: Preliminary Report. medRxiv, 2020.2006.2022.20137273 (2020).

20. D. A. Drew et al., Rapid implementation of mobile technology for real-time epidemiology of COVID19. Science, (2020).

21. W. M. van der Wal, R. B. Geskus, ipw: An R Package for Inverse Probability Weighting. Journal of Statistical Software; Vol 1, Issue 13 (2011), (2011).

Acknowledgments: We would like to thank the contributing citizen researchers who participated in the COVID Symptom Study and participants of the studies within the COronavirus Pandemic Epidemiology (COPE) Consortium. Funding: Zoe provided in kind support for all aspects of building, running and supporting the app and service to all users worldwide. DAD is supported by the National Institute of Diabetes and Digestive and Kidney Diseases K01DK120742. CGG is supported by the Bau Tsu Zung Bau Kwan Yeu Hing Research and Clinical Fellowship. LHN is supported by the American Gastroenterological Association Research Scholars Award. ATC is the Stuart and Suzanne Steele MGH Research Scholar and Stand Up to Cancer scientist. The Massachusetts Consortium on Pathogen Readiness (MassCPR) and Mark and Lisa Schwartz supported MGH investigators (DAD, CGG, LHN, ADJ, WM, RSM, CHL, SK, ATC). CMA is supported by the NIDDK K23 DK120899 and the Boston Children's Hospital Office of Faculty Development Career Development Award. King's College of London investigators (KAL, MNL, TV, MSG, CHS, SO, CJS, TDS) were supported by the Wellcome Trust and EPSRC (WT212904/Z/18/Z, WT203148/Z/16/Z, T213038/Z/18/Z), the NIHR GSTT/KCL Biomedical Research Centre, MRC/BHF (MR/M016560/1), UK Research and Innovation London Medical Imaging \& Artificial Intelligence Centre for Value Based Healthcare, and the Alzheimer's Society (AS-JF-17011). MNL is supported by an NIHR Doctoral Fellowship (NIHR300159). Work related to the Swedish elements of the study are supported by grants from the Swedish Research Council, Swedish Heart-Lung 
medRxiv preprint doi: https://doi.org/10.1101/2021.04.28.21256261; this version posted May 2, 2021. The copyright holder for this preprint (which was not certified by peer review) is the author/funder, who has granted medRxiv a license to display the preprint in perpetuity.

It is made available under a CC-BY-NC-ND 4.0 International license .

Foundation and the Swedish Foundation for Strategic Research (LUDC-IRC 15-0067). Sponsors had no role in study design, analysis, and interpretation of data, report writing, and the decision to submit for publication. The corresponding author had full access to data and the final responsibility to submit for publication. Author contributions: DAD, CGG, and ATC performed formal analysis. DAD, CGG, and KAL drafted the initial manuscript. All authors contributed to the conceptualization, methodology, investigation, resources, data curation, and review and editing of the manuscript. ATC supervised the study. Competing interests: JW, RD, and JC are employees of Zoe Global Ltd. TDS is a consultant to Zoe Global Ltd. DAD and ATC previously served as investigators on a clinical trial of diet and lifestyle using a separate mobile application that was supported by Zoe Global Ltd. Other authors have no conflict of interest to declare. Data and materials availability: Data collected in the app is being shared with other health researchers through the NHS-funded Health Data Research U.K. (HDRUK)/SAIL consortium, housed in the U.K. Secure Research Platform (UKSeRP) in Swansea. Anonymized data is available to be shared with bonafide researchers HDRUK according to their protocols (https://healthdatagateway.org/detail/9b604483-9cdc-41b2-b82c-14ee3dd705f6). U.S. investigators are encouraged to coordinate data requests through the COPE Consortium (www.monganinstitute.org/cope-consortium). Data updates can be found on https://covid.joinzoe.com. 
medRxiv preprint doi: https://doi.org/10.1101/2021.04.28.21256261; this version posted May 2, 2021. The copyright holder for this preprint (which was not certified by peer review) is the author/funder, who has granted medRxiv a license to display the preprint in perpetuity.

It is made available under a CC-BY-NC-ND 4.0 International license .

Table 1. Baseline characteristics of entire study cohort

\begin{tabular}{|c|c|c|}
\hline & $\begin{array}{c}\text { Non-NSAID users } \\
(n=2,4947,80)\end{array}$ & $\begin{array}{c}\text { Any NSAID users } \\
(n=241,311)\end{array}$ \\
\hline \multicolumn{3}{|l|}{ Country, \% } \\
\hline United States & 5.1 & 19.4 \\
\hline United Kingdom & 91.8 & 76.1 \\
\hline Sweden & 3.1 & 4.5 \\
\hline Age (years) & $44.0[32.0,57.0]$ & $55.00[43.0,67.0]$ \\
\hline$<25$ & 12.4 & 4.1 \\
\hline $25-34$ & 18.6 & 9.7 \\
\hline $35-44$ & 20.8 & 14.3 \\
\hline $45-54$ & 19.5 & 19.9 \\
\hline $55-64$ & 16.2 & 21.6 \\
\hline \multirow[t]{2}{*}{$\geq 65$} & 12.5 & 30.4 \\
\hline & 0.4 & 0 \\
\hline Male sex, $\%$ & 37.9 & 37.2 \\
\hline \multicolumn{3}{|l|}{ Race/Ethnicity, \% } \\
\hline White, non-Hispanic & 62.1 & 60.9 \\
\hline Other & 3.6 & 3.0 \\
\hline Prefer not to say & 0.3 & 0.3 \\
\hline Missing & 34.1 & 35.9 \\
\hline BMI $\left(\mathrm{kg} / \mathrm{m}^{2}\right)$ & $25.16[22.32,28.84]$ & $27.40[24.11,31.89]$ \\
\hline $17-18.4$ & 44.0 & 30.2 \\
\hline 18.5-24.9 & 4.6 & 2.0 \\
\hline $25-29.9$ & 31.4 & 34.0 \\
\hline$\geq 30$ & 19.9 & 33.8 \\
\hline \multicolumn{3}{|l|}{ Comorbidities, \% } \\
\hline Diabetes & 2.8 & 8.8 \\
\hline Heart Disease & 1.8 & 11.8 \\
\hline Lung Disease & 11.7 & 16.7 \\
\hline Kidney Disease & 0.6 & 1.6 \\
\hline Cancer & 0.6 & 2.1 \\
\hline \multicolumn{3}{|l|}{ Medication usage, $\%$} \\
\hline Immunosuppressants & 2.8 & 8.2 \\
\hline Chemo/Immunotherapy & 0.2 & 0.6 \\
\hline Blood pressure medications & 5.6 & 23.0 \\
\hline Current smoker, $\%$ & 4.1 & 3.8 \\
\hline Limited mobility, $\% \dagger$ & 4.0 & 14.8 \\
\hline Mobility aid, \% & 1.4 & 8.0 \\
\hline Frontline healthcare worker, $\%$ & 5.0 & 6.1 \\
\hline Contact with suspected or documented COVID-19 cases, \% & 6.6 & 8.1 \\
\hline \multicolumn{3}{|c|}{$\begin{array}{l}\text { Abbreviations: BMI (body mass index), kg (kilogram), m (meter), NSAIDs (non-steroidal anti-inflammatory drugs), S.E. (Sweden). } \\
\text { U.S. (United States), U.K. (United Kingdom) } \\
\text { Median [IQR] is presented for continuous variables. } \\
\text { Frequencies and proportions are calculated based on the total number of participants with available data. } \\
\text { History of cancer, aspirin use, and smoking status have been queried since launch in the U.S. and since } 3 / 29 / 2020 \text { in the U.K. Race and } \\
\text { ethnicity questions were queried as of } 4 / 17 / 2020 \text { and percentages reflect the distribution among the } 1,799,672 \text { that provided data. } \\
\dagger \text { Asked as "In general, do you have any health problems that require you to stay at home?" } \\
\text { † Asked as "Do you regularly use a stick, walking frame or wheelchair to get about?" }\end{array}$} \\
\hline
\end{tabular}


Table 2. Risk of testing positive for COVID-19 according to aspirin or NSAID use

\begin{tabular}{|c|c|c|c|c|c|}
\hline & & & \multicolumn{3}{|c|}{ Hazard Ratio (95\% CI) } \\
\hline & $\begin{array}{l}\text { No. with Event/ Person- } \\
\text { time (days) }\end{array}$ & $\begin{array}{l}\text { 30-day } \\
\text { incidence }\end{array}$ & $\begin{array}{l}\text { Multivariable } \\
\text { Stratification }\end{array}$ & $\begin{array}{l}\text { Comorbidity- } \\
\text { adjusted }\end{array}$ & $\begin{array}{l}\text { Comorbidity and } \\
\text { Symptom- } \\
\text { adjusted }\end{array}$ \\
\hline \multicolumn{6}{|l|}{ Any NSAID Use } \\
\hline $\begin{array}{l}\text { Positive COVID-19 testing } \\
\text { Non users } \\
\text { Any NSAID users }\end{array}$ & $\begin{array}{c}8191 / 56112463 \\
775 / 4704580\end{array}$ & $\begin{array}{l}0.44 \% \\
0.49 \%\end{array}$ & $\begin{array}{c}1.0 \text { (ref.) } \\
1.22(1.13,1.32)\end{array}$ & $\begin{array}{c}1.0 \text { (ref.) } \\
1.15(1.06,1.24)\end{array}$ & $\begin{array}{c}1.0 \text { (ref.) } \\
1.02(0.94,1.10)\end{array}$ \\
\hline $\begin{array}{l}\text { Positive COVID-19 and wa } \\
\text { hospital/clinic } \\
\text { Non users } \\
\text { Any NSAID users }\end{array}$ & $\begin{array}{c}1316 / 56112463 \\
209 / 4704580\end{array}$ & $\begin{array}{l}0.07 \% \\
0.13 \%\end{array}$ & $\begin{array}{c}1.0 \text { (ref.) } \\
1.77(1.52,2.06)\end{array}$ & $\begin{array}{c}1.0 \text { (ref.) } \\
1.37(1.17,1.60)\end{array}$ & $\begin{array}{c}1.0 \text { (ref.) } \\
1.13(0.96,1.32)\end{array}$ \\
\hline \multicolumn{6}{|c|}{$\underline{\text { Aspirin or non-aspirin NSAID Use }}^{\dagger}$} \\
\hline $\begin{array}{l}\text { Positive COVID-19 testing } \\
\text { Non users } \\
\text { Aspirin users } \\
\text { Non-aspirin NSAID users } \\
\text { Aspirin and NSAID users }\end{array}$ & $\begin{array}{c}3026 / 18423122 \\
105 / 1037175 \\
297 / 1399965 \\
25 / 172090\end{array}$ & $\begin{array}{l}0.49 \% \\
0.30 \% \\
0.64 \% \\
0.44 \%\end{array}$ & $\begin{array}{c}1.0 \text { (ref.) } \\
1.13(0.92,1.38) \\
1.23(1.09,1.39) \\
1.26(0.85,1.88)\end{array}$ & $\begin{array}{c}1.0 \text { (ref.) } \\
1.07(0.86,1.33) \\
1.16(1.02,1.31) \\
1.16(0.77,1.74)\end{array}$ & $\begin{array}{c}1.0 \text { (ref.) } \\
1.03(0.83,1.28) \\
0.98(0.87,1.11) \\
0.91(0.60,1.38)\end{array}$ \\
\hline $\begin{array}{l}\text { Positive COVID-19 and wa } \\
\text { hospital/clinic } \\
\text { Non users } \\
\text { Aspirin users } \\
\text { Non-aspirin NSAID users } \\
\text { Aspirin and NSAID users }\end{array}$ & $\begin{array}{c}490 / 18423122 \\
23 / 1037175 \\
76 / 1399965 \\
11 / 172090\end{array}$ & $\begin{array}{l}0.08 \% \\
0.07 \% \\
0.16 \% \\
0.19 \%\end{array}$ & $\begin{array}{c}1.0 \text { (ref.) } \\
1.06(0.68,1.64) \\
1.68(1.31,2.15) \\
2.35(1.27,4.35)\end{array}$ & $\begin{array}{c}1.0 \text { (ref.) } \\
0.82(0.52,1.29) \\
1.37(1.06,1.76) \\
1.64(0.88,3.06)\end{array}$ & $\begin{array}{c}1.0 \text { (ref.) } \\
0.78(0.49,1.24) \\
1.06(0.81,1.38) \\
0.99(0.50,1.93)\end{array}$ \\
\hline \multicolumn{6}{|c|}{$\begin{array}{l}\text { Abbreviations: CI (confidence interval) } \\
\text { †This analysis excludes anyone who responded prior to March } 30^{\text {th }} \text { where aspirin use was not specifically queried separately from other NSAID use at baseline. } \\
\text { Multivariable Stratification model: Cox proportional hazards model stratified by } 5 \text {-year age group, sex, race, calendar date at study entry, and country. } \\
\text { Comorbidity-adjusted model: Cox proportional hazards model stratified by factors in multivariable stratification model plus further adjustment for history of diabetes, heart disease, lung } \\
\text { disease, kidney disease, cancer, limited mobility, mobility aid, blood pressure medications, chemotherapy/immunotherapy, immunosuppressants, and current smoker status (each yes/no), } \\
\text { and body mass index }\left(17-19.9,20-24.9,25-29.9 \text {, and } \geq 30 \mathrm{~kg} / \mathrm{m}^{2}\right) \text {. } \\
\text { Comorbidity and Symptom-adjusted model: Cox proportional hazards model adjusted for all factors included in the comorbidity-adjusted model with further adjustment for symptoms at } \\
\text { baseline. }\end{array}$} \\
\hline
\end{tabular}




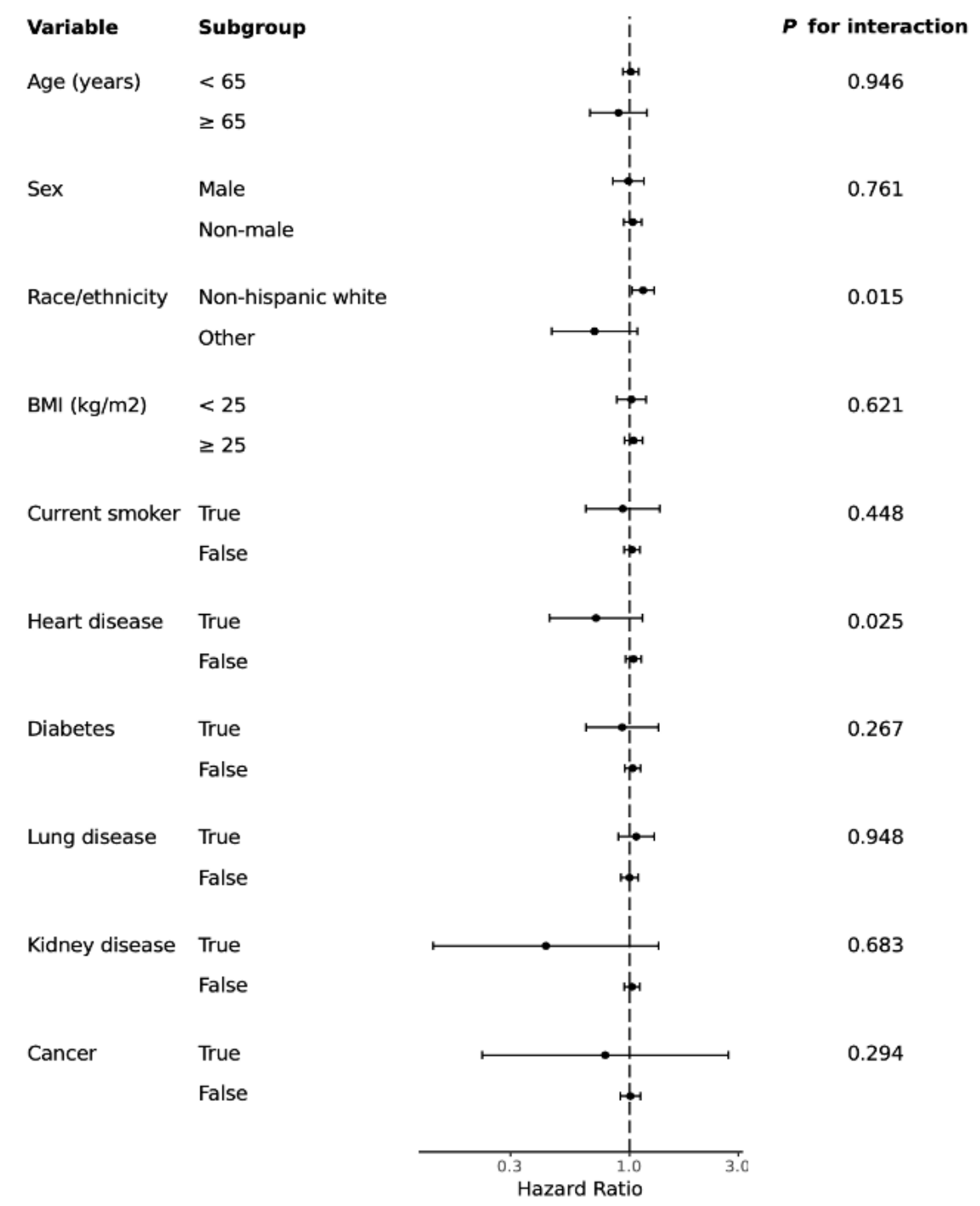

Figure 1. Association of NSAID use with COVID-19 according to strata of demographic, lifestyle, and comorbid factors. 
Supplemental Table 1. Baseline characteristics according to use of aspirin, non-aspirin NSAIDs, or Both (Cohort restricted to 3/30 baseline)

\begin{tabular}{|c|c|c|c|c|}
\hline & $\begin{array}{c}\text { Non users } \\
(n=1,255,781)\end{array}$ & $\begin{array}{c}\text { Aspirin users } \\
(n=653,86)\end{array}$ & $\begin{array}{c}\text { Non-aspirin NSAID users } \\
(\boldsymbol{n}=93,867)\end{array}$ & $\begin{array}{c}\text { Aspirin and NSAID users } \\
(n=11,293)\end{array}$ \\
\hline \multicolumn{5}{|l|}{ Country, \% } \\
\hline U.S. & 10.0 & 30.1 & 22.8 & 46.0 \\
\hline U.K. & 83.8 & 64.5 & 70.6 & 44.8 \\
\hline S.E. & 6.1 & 5.4 & 6.6 & 9.2 \\
\hline Age (years) & $47.0[32.0,60.0]$ & $68.0[60.0,74.0]$ & $52.0[41.0,63.0]$ & $65.00[54.0,72.0]$ \\
\hline$<25$ & 16.2 & 0.6 & 4.7 & 2.6 \\
\hline $25-34$ & 12.7 & 1.6 & 9.6 & 4.1 \\
\hline $35-44$ & 16.3 & 3.1 & 16.5 & 6.2 \\
\hline $45-54$ & 19.3 & 9.1 & 24.4 & 12.7 \\
\hline $55-64$ & 18.1 & 24.1 & 22.8 & 24.1 \\
\hline$\geq 65$ & 17.4 & 61.5 & 22.1 & 50.3 \\
\hline $\begin{array}{l}\text { Male sex, \% } \\
\end{array}$ & 43.9 & 58.8 & 31.5 & 44.6 \\
\hline \multicolumn{5}{|l|}{ Race/Ethnicity, \% } \\
\hline White, non-Hispanic & 72.5 & 68.7 & 63.8 & 55.0 \\
\hline Other & 4.3 & 4.0 & 3.0 & 3.3 \\
\hline Prefer not to say & 0.3 & 0.3 & 0.3 & 0.3 \\
\hline BMI $\left(\mathbf{k g} / \mathbf{m}^{2}\right)$ & $25.1[22.1,28.8]$ & $27.1[24.2,30.7]$ & $27.6[24.1,32.3]$ & $28.3[24.9,32.9]$ \\
\hline $17-18.4$ & 41.8 & 30.2 & 29.5 & 24.1 \\
\hline $18.5-24.9$ & 7.0 & 1.9 & 2.2 & 2.1 \\
\hline $25-29.9$ & 31.3 & 39.2 & 32.6 & 34.3 \\
\hline$\geq 30$ & 19.9 & 28.6 & 35.7 & 39.5 \\
\hline \multicolumn{5}{|l|}{ Comorbidities, \% } \\
\hline Diabetes & 3.4 & 17.3 & 5.6 & 16.4 \\
\hline Heart Disease & 2.2 & 33.1 & 2.7 & 20.6 \\
\hline Lung Disease & 11.5 & 14.6 & 17.1 & 19.1 \\
\hline Kidney Disease & 0.7 & 3.8 & 0.9 & 2.0 \\
\hline Cancer & 1.2 & 4.4 & 1.8 & 3.7 \\
\hline \multicolumn{5}{|l|}{ Medication usage, $\%$} \\
\hline Immunosuppressants & 3.1 & 6.9 & 8.6 & 10.8 \\
\hline Chemo/Immunotherapy & 0.2 & 1.0 & 0.3 & 0.8 \\
\hline Blood pressure medications & 9.6 & 49.5 & 16.7 & 46.0 \\
\hline Current smoker, \% & 0.1 & 0 & 0.2 & 0 \\
\hline Limited mobility, \%† & 6.4 & 21.0 & 14.8 & 21.4 \\
\hline Mobility aid, \% & 2.0 & 8.7 & 8.2 & 13.8 \\
\hline Frontline healthcare worker, \% & 6.1 & 4.1 & 8.6 & 6.8 \\
\hline Interaction with suspected or documented COVID-19, \% & 12.1 & 6.8 & 13.7 & 9.6 \\
\hline $\begin{array}{l}\text { Abbreviations: BMI (body mass index), kg (kilogram), m (me } \\
\text { Median [IQR] is presented for continuous variables. } \\
\text { Frequencies and proportions are calculated based on the total } \\
\text { History of cancer, aspirin use, and smoking status have been } \\
\text { participants providing data. } \\
\dagger \text { Asked as "In general, do you have any health problems that } \\
\$ \text { Asked as "Do you regularly use a stick, walking frame or } \\
+ \text { w }\end{array}$ & $\begin{array}{l}\text { s (non-steroidal an } \\
\text { articipants with av } \\
\text { e launch in the U.S } \\
\text { to stay at home?" } \\
\text { get about?" }\end{array}$ & 9/2020 in the U.K. & thnicity questions were queri & of $4 / 17 / 2020$ with $1,085,282$ \\
\hline
\end{tabular}




\section{Supplemental Table 2. Aspirin and non-aspirin NSAIDs and symptom occurrence}

\begin{tabular}{|c|c|c|c|c|}
\hline & \multicolumn{4}{|c|}{ Aspirin or Non-aspirin NSAID Use } \\
\hline & $\begin{array}{c}\text { Non users } \\
(\mathrm{n}=1,255,781)\end{array}$ & $\begin{array}{c}\text { Aspirin users } \\
(\mathrm{n}=65,386)\end{array}$ & $\begin{array}{c}\text { Non-aspirin NSAID users } \\
\qquad(\mathrm{n}=93,867)\end{array}$ & $\begin{array}{l}\text { Aspirin and NSAID users } \\
(\mathrm{n}=11,293)\end{array}$ \\
\hline Asymptomatic & 78.0 & 82.7 & 65.8 & 72.0 \\
\hline Symptomatic & 22.0 & 17.3 & 34.2 & 28.0 \\
\hline \multicolumn{5}{|c|}{ Individual symptoms (\% of those reporting at least 1 symptom) } \\
\hline Fatigue & 58.6 & 60.6 & 67.0 & 67.4 \\
\hline Headache & 56.2 & 51.0 & 66.2 & 62.7 \\
\hline Sore throat & 43.8 & 36.1 & 46.2 & 40.1 \\
\hline Shortness of breath & 24.1 & 25.2 & 30.3 & 32.6 \\
\hline Chest pain & 25.0 & 22.2 & 29.3 & 27.5 \\
\hline Diarrhea & 21.8 & 22.4 & 28.3 & 27.6 \\
\hline Skipped meals/anorexia & 19.1 & 20.7 & 27.3 & 27.6 \\
\hline Myalgias & 16.4 & 20.0 & 25.8 & 29.4 \\
\hline Persistent Cough & 22.8 & 22.5 & 25.7 & 25.4 \\
\hline Abdominal pain & 19.7 & 20.7 & 25.2 & 25.3 \\
\hline Delirium & 14.2 & 18.5 & 21.2 & 24.2 \\
\hline Hoarse voice & 15.9 & 17.4 & 19.9 & 19.4 \\
\hline Fever & 13.1 & 12.1 & 15.7 & 17.1 \\
\hline Loss of smell/taste & 13.6 & 11.5 & 15.2 & 14.4 \\
\hline
\end{tabular}

